九州大学学術情報リポジトリ

Kyushu University Institutional Repository

\title{
Analyses of Accumulation of Silica in the Growth of Two Tropical Forages using Simple
} Equations

Shimojo, Masataka

Laboratory of Animal Feed Science, Faculty of Agriculture, Kyushu University

Bungo, Takashi

Laboratory of Animal Feed Science, Faculty of Agriculture, Kyushu University

Tobisa, Manabu

Laboratory of Animal Feed Science, Faculty of Agriculture, Kyushu University

Imura, Yoshimi

Laboratory of Animal Feed Science, Faculty of Agriculture, Kyushu University

他

https://doi.org/10.5109/24285

出版情報 : 九州大学大学院農学研究院紀要. 43 (3/4)，pp. 395-401，1999-02. Kyushu University バージョン：

権利関係： 


\title{
Analyses of Accumulation of Silica in the Growth of Two Tropical Forages using Simple Equations
}

\author{
Masataka Shimojo, Takashi Bungo, Manabu Tobisa, Yoshimi Imura, \\ Naoki Koga, Tao Shao, Muhammad Yunus, Yutaka Nakano*, \\ Ichiro Goto**, Mitsuhiro Furuse and Yasuhisa Masuda
}

\author{
Laboratory of Animal Feed Science, Faculty of Agriculture, \\ Kyushu Iniversity, Fukuoka 8128581 . Japan \\ (Receined October 30, 1998 and accepted November 6, 1998)
}

The present study was conducted, using simple equations, to anialyze the accumulation rate of silica [ARSi], that of minerals [ARM] and silica content changes with growth of Rhodes grass [Rg] and Grecnleaf desmodium [Gd]. The following two equations were suggested for analyses:

$$
\begin{aligned}
& \mathrm{ARSi}=\frac{1}{W} \cdot \frac{d(S i)}{d t}=\left(\begin{array}{c}
1 \\
W
\end{array} \cdot \frac{d M}{d t}\right) \cdot \frac{d\left(S_{i}\right)}{d M}, \\
& \text { Changes in silica content }=\begin{array}{c}
1000 \\
1
\end{array} \cdot\left(\begin{array}{cc}
(S i)_{2} & (S i)_{1} \\
W_{2} & W_{1}
\end{array}\right) \\
& =\left(1-\frac{W_{1}}{W_{2}}\right) \cdot\left\{\frac{1}{1000} \cdot\left(\frac{\overline{\mathrm{ARSi}}}{\overline{\mathrm{RGR}}}-\frac{\left(S_{i}\right)_{1}}{W_{1}}\right)\right\} \text {. }
\end{aligned}
$$

where $W=$ forage dry weight $\left(g / \mathrm{m}^{2}\right), S i=$ amount of silica in the forage $\left(\mathrm{mg} / \mathrm{m}^{2}\right), M=$ amount of minerals in the forage $\left.\left(\mathrm{mg} / \mathrm{m}^{2}\right),(1 / W) \cdot(d / S i) / d t\right)=\mathrm{ARSi},(1 / W) \cdot(d M / d t)=\mathrm{ARM},(d(S i) / d M)=$ accumulation of silica per unit accumulation of $M$ [ASiAM], $\overline{\mathrm{RGR}}=$ mean relative growth rate [RGR] of forages over the interval $t_{1}$ to $t_{2}, \overline{\mathrm{ARSi}}=$ mean ARSi over the interval $t_{1}$ to $t_{2},\left(1-W_{1} / W_{2}\right)=$ forage growth index $[\mathrm{FG}$ index], $\{\mathrm{ARSi} / \mathrm{RGR}-(\mathrm{Si}) / W\} / 1000=$ an index for forage growth dependent silica accumulation [F(iDSiA index].

Analyses using equation (A) suggested that $\mathrm{Rg}$ showed a higher selection of silica in the accumulation of minerals, when compared with Gd. Analyses using equation (B) suggested that Rg showed less active silica accumulation than forage growth, in contrast to more active silica accumulation than forage growth in Gd. It was suggested that the present methods accounted analytically for the accumulation characteristics of silica and its content changes with growth of forages.

\section{INTRODUCTION}

Silica, as well as other minerals, is absorbed from soil by plant roots, and the absorbed silica is deposited on plant fibers (Jones and Handreck, 1967). It is reported that silica depresses forage digestibility (Smith and Nelson, 1975; Smith and Urquhart, 1975; Van Soest, 1982; Shimojo and Goto, 1985, 1989; Minson, 1990). The content of silica is lower than that of lignin unless forages are grown on soil rich in silica or under water-logging

\footnotetext{
* Kyushu University Farm, Fukuoka 811-2307

** University of the Air, Fukuoka Study Center, Fukuoka 812-0016
} 
condition like a paddy field. In many cases, therefore, the depression of forage digestibility by silica seems to be smaller than that by lignin. This is why we have so far taken up lignification only in the analysis, using simple equations, of the formation of indigestible materials with growth of forages (Shimojo et al., 1995, 1997a, b, 1998a, d, g, h, i, 1999a, b, c).

It is considered of interest to apply simple equations to analyses of the absorption and accumulation of silica with growth of forages. Tobisa et al. (1997) analyzed, using the equation suggested by Hunt (1990), the absorption of some minerals by the root of Aeschynomene americana $\mathrm{cv}$. Glenn when grown under the water-logging condition. To the analysis of the accumulation of silica, simple equations, which were suggested to the analysis of the accumulation of digestible materials (Shimojo et al., 1998b, f, h, 1999a, b, c) and that of crude protein (Shimojo et $a l ., 1998 \mathrm{c}, \mathrm{e}$ ) with forage growth, might be expected to be applied, if modified appropriately.

The present study was designed to suggest simple equations to analyses of the accumulation of silica and its content changes with growth of forages, followed by applying them to two tropical forages, a grass and a forage legume.

\section{EQUATIONS FOR ANALYZING ACCUMULATION OF SILICA AND ITS CONTENT CHANGES WITH FORAGE GROWTH}

\section{An equation suggested to the analysis of silica accumulation}

An equation for describing silica accumulation rate per unit dry weight of the forage [ARSi] with its growth is suggested as follows:

$\mathrm{ARSi}=\frac{1}{W} \cdot \frac{d(S i)}{d t}$

where $W=$ forage dry weight $\left(\mathrm{g} / \mathrm{m}^{2}\right), S i=$ amount of silica in the forage $\left(\mathrm{mg} / \mathrm{m}^{2}\right)$.

Silica is actually absorbed by plants as a part of minerals, therefore, equation (1) is rewritten as follows:

$$
\begin{aligned}
\text { ARSi } & =\frac{1}{W} \cdot \frac{d(S i)}{d t} \\
& =\left(\frac{1}{W} \cdot \frac{d M}{d t}\right) \cdot \frac{d(S i)}{d M},
\end{aligned}
$$

where $M=$ amount of minerals in the forage $\left(\mathrm{mg} / \mathrm{m}^{2}\right),(1 / W) \cdot(d M / d t)=$ accumulation rate of minerals per unit $W$ [ARM], $d(S i) / d M=$ accumulation of silica per unit accumulation of $M$ [ASiAM].

Mean value over the interval $t_{1}$ to $t_{2}$ for each of ARSi, ARM and ASiAM is approximately as follows:

$$
\begin{aligned}
& \overline{\mathrm{ARSi}}=\frac{\log _{e} W_{2}-\log _{e} W_{1}}{W_{2}-W_{1}} \cdot \frac{(S i)_{2}-(S i)_{1}}{t_{2}-t_{1}}, \\
& \overline{\mathrm{ARM}}=\frac{\log _{e} W_{2}-\log _{e} W_{1}}{W_{2}-W_{1}} \cdot \frac{M_{2}-M_{1}}{t_{2}-t_{1}}, \\
& \overline{\mathrm{ASiAM}}=\frac{(S i)_{2}-(S i)_{1}}{M_{2}-M_{1}},
\end{aligned}
$$


where $e=$ the base of natural logarithm.

\section{An equation suggested to the analysis of silica content changes}

An equation for describing changes in silica content with forage growth is suggested as follows:

$$
\begin{aligned}
\text { Chages in silica content } & =\frac{1}{1000} \cdot\left(\frac{(S i)_{2}}{W_{2}}-\frac{(S i)_{1}}{W_{1}}\right) \\
& =\left(1-\frac{W_{1}}{W_{2}}\right) \cdot\left\{\frac{1}{1000} \cdot\left(\frac{\overline{\mathrm{ARSi}}}{\overline{\mathrm{RGR}}}-\frac{(S i)_{1}}{W_{1}}\right)\right\},
\end{aligned}
$$

where $\overline{\mathrm{ARSi}}=$ mean ARSi over the interval $t_{1}$ to $t_{2}, \mathrm{RGR}=$ forage relative growth rate $[(1 / W) \cdot(d W / d t)], \overline{\mathrm{RGR}}=$ mean RGR over the interval $t_{1}$ to $t_{2},\left(1-W_{1} / W_{3}\right)=$ forage growth index [FG index], $\left\{\overline{\mathrm{ARSi}} \overline{\mathrm{RGR}}-(\mathrm{Si}), / W_{1}\right\} / 1000=$ an index for forage growth dependent silica accumulation [FGDSiA index].

$\overline{\mathrm{RGR}}$ is approximately as follows:

$$
\overline{\mathrm{R}} \mathrm{GR}=\frac{\log _{e} W_{2}-\log _{e} W_{1}}{t_{2}-t_{1}}
$$

Equation (6) is given according to the following procedures:

$$
\begin{aligned}
\frac{(S i)_{2}}{W_{2}}-\frac{(S i)_{1}}{W_{1}}=\frac{(S i)_{1}}{W_{1}}+ & \Delta W \\
& =\frac{\Delta W}{W_{1}+\Delta W}-\frac{(S i)_{1}}{W_{1}} \\
& =\frac{\Delta S i}{W_{2}}-\frac{(S i)_{1} \cdot \Delta W}{W_{1} \cdot\left(W_{1}+\Delta W\right)} \\
& =\frac{\Delta W}{W_{2}} \cdot\left(\frac{\Delta S i}{\Delta W}-\frac{(S i)_{1}}{W_{1}}\right) .
\end{aligned}
$$

Then, the ratio of ARSi to ROR is taken un as follows:

$$
\begin{aligned}
\frac{\mathrm{ARSi}}{\mathrm{RGR}}= & \frac{\frac{1}{W} \cdot \frac{d(S i)}{d t}}{\underset{W}{1} \cdot d \underline{W}} \\
& =\frac{d(S i)}{d W} .
\end{aligned}
$$

Thus, the following relation is suggested,

$$
\frac{\Delta S i}{\Delta W}=\frac{\overline{\mathrm{ARSi}}}{\overline{\mathrm{RGR}}} \text {. }
$$

Inserting equation (10) into equation (8) gives

$\frac{(S i)_{2}}{W_{2}}-\frac{(S i)_{1}}{W_{1}}=\frac{\Delta W}{W_{2}} \cdot\left(\frac{\overline{\mathrm{ARSi}}}{\overline{\mathrm{RGR}}}-\frac{(S i)_{1}}{W_{1}}\right)$ 


$$
\begin{aligned}
& =\frac{W_{2}-W_{1}}{W_{2}} \cdot\left(\frac{\overline{\mathrm{ARSi}}}{\operatorname{RGR}}-\frac{(S i)_{1}}{W_{1}}\right) \\
& =\left(1-\frac{W_{1}}{W_{2}}\right) \cdot\left(\frac{\overline{\mathrm{ARSi}}}{\overline{\mathrm{RGR}}}-\frac{(S i)_{1}}{W_{1}}\right)
\end{aligned}
$$

Dividing equation (11) by 1000 gives equation (6).

\section{AN APPLICATION OF SUGGESTED EQUATIONS TO TWO TROPICAL FORAGES}

\section{Forages}

Two tropical forages are Rhodes grass (Chloris gayana Kunth) and Greenleaf desmodium (Desmodium intortum (Mill.) Urb.) which were cut at 35 and 63 days of regrowth with a compound fertilizer $\left(\mathrm{N}_{2} \mathrm{P}_{2} \mathrm{O}_{5}: \mathrm{K}_{2} \mathrm{O}=14: 14: 14 \%\right)$ dressed at a rate of $1.0 \mathrm{~kg} / \mathrm{a}$ for each element immediately after the first cut and discard. Forage dry weight was determined by drying at $70^{\circ} \mathrm{C}$ for $48 \mathrm{hr}$, minerals were determined by combustion at $600^{\circ} \mathrm{C}$ for $3 \mathrm{hr}$, and silica was determined using the method of Goering and Van Soest (1970).

Characteristics of Rhodes grass [Rg] and Greenleaf desmodium [Gd] are shown in Table 1. The silica content in forage $(\mathrm{g} / \mathrm{g})$ was higher in $\mathrm{Rg}$ than in $\mathrm{Gd}$ at both days of regrowth ( 0.0156 versus 0.0024 at 35 days, 0.0123 versus 0.0032 at 63 days). This is in agreement with the review article on forage silica by Wilson (1982) that grasses generally contain higher amount of silica than forage legumes. Mineral content in forage $(g / g)$ is higher in $\mathrm{Rg}$ than in $\mathrm{Gd}$ at both days of regrowth ( 0.1146 versus 0.0841 at 35 days, 0.0798 versus 0.0705 at 63 days), but the content difference between $\mathrm{Rg}$ and Gd decreased with growth of them. Silica concentration in minerals $(\mathrm{g} / \mathrm{g})$ is higher in Rg than in Gd at both

\begin{tabular}{|c|c|c|c|c|}
\hline \multirow{2}{*}{$\begin{array}{l}\text { Forages } \\
\text { Regrowth(days) }\end{array}$} & \multicolumn{2}{|c|}{$\mathrm{Rg}$} & \multicolumn{2}{|c|}{ Gd } \\
\hline & 35 & 63 & 35 & 63 \\
\hline Forage dry weight: $W\left(\mathrm{~g} / \mathrm{m}^{2}\right)$ & 225.56 & 515.00 & 190.00 & 315.28 \\
\hline Silica amount, in forage: $S i\left(\mathrm{~g} / \mathrm{m}^{2}\right)$ & 3.51 & 6.36 & 0.46 & 1.00 \\
\hline $\operatorname{ditto}: \operatorname{Si}\left(\mathrm{mg} / \mathrm{m}^{3}\right)$ & 3510.0 & 6360.0 & 460.0 & 1000.0 \\
\hline Silica content in forage $(g / g)$ & 0.0156 & 0.0123 & 0.0024 & 0.0032 \\
\hline Mineral amount in forage: $M\left(\mathrm{~g} / \mathrm{m}^{2}\right)$ & 25.85 & 41.10 & 15.98 & 22.23 \\
\hline ditto: $M\left(\mathrm{mg} / \mathrm{m}^{\prime}\right)$ & 25850.0 & 41100.0 & 15980.0 & 22230.0 \\
\hline Mineral content in forage $(\mathrm{g} / \mathrm{g})$ & 0.1146 & 0.0798 & 0.0841 & 0.0705 \\
\hline Silica concentration in uninerals $(\mathrm{g} / \mathrm{g})$ & 0.1358 & 0.1547 & 0.0288 & 0.0450 \\
\hline
\end{tabular}

Table 1. Characteristics of Rhodes grass [Rg] and Greenleaf desmodium [Gd].

Silica: determined using the method of Goering and Van Soest (1970).

Minerals: determined as crude ash by the combustion of forages at $600^{\circ} \mathrm{C}$ for $3 \mathrm{hr}$. 
days of regrowth ( 0.1358 versus 0.0288 at 35 days, 0.1547 versus 0.0450 at 63 days), and the concentration increased with growth in both $\mathrm{Rg}$ and $\mathrm{Gd}$.

\section{Accumulation of silica with growth of $\mathrm{Rg}$ and $\mathrm{Gd}$}

The accumulation of silica in Rg and Dg analyzed using ARSi, ARM and ASiAM over the interval of 28 days of regrowth are shown in Table $2 a$. ARSi was higher in Rg than in Gd $(0.2903$ versus 0.0780$)$, and this was due to both higher $\overline{\mathrm{ARM}}(1.5535)$ and $\overline{\mathrm{ASiAM}}$ $(0.1869)$ in Rg compared with those ( 0.9023 and 0.0864 , respectively) in Gd. The ratio of $\mathrm{Rg}$ to $\mathrm{Gd}$ in ARSi (3.7240) was higher than that in $\overline{\mathrm{ARM}}$ (1.7217), suggesting that $\mathrm{Rg}$ showed a higher selection of silica in the accumulation of minerals, when compared with Gd. This resulted in the ratio of $\mathrm{Rg}$ to Gd in $\overline{\mathrm{ASiAM}}$ to be 2.1630 . It is suggested that the present method accounts analytically for how silica and minerals accumulate with growth of forages and how the accumulation of them shows differences between forages.

\section{Changes in silica content with growth of Rg and Gd}

Changes in silica content analyzed using FG index and FGDSiA index over the interval of 28 days are shown in Table $2 b$. The change in silica content was -0.0032 for $\mathrm{Rg}$

Table 2. Analyses of the accumulation of silica and changes in its content with growth of Rhodes grass [Rg] and Greenleaf desmodium [Gd].

a) Analysis of the accumulation of silica with growth of Rg and Gd.

\begin{tabular}{lccc}
\hline Forages & $\mathrm{Rg}$ & $\mathrm{Gd}$ & $\mathrm{Rg} / \mathrm{Gd}$ \\
Interval(days) & 28 & 28 & \\
\hline$\overline{\mathrm{ARSi}}$ (mg/g/day) & 0.2903 & 0.0780 & 3.7240 \\
$\overline{\mathrm{ARM}}$ (mg/g/day) & 1.5535 & 0.9023 & 1.7217 \\
$\overline{\mathrm{ASiAM}}$ (mg/mg) & 0.1869 & 0.0864 & 2.1630 \\
\hline
\end{tabular}

ARSi=accumulation rate of silica per unit $W, \mathrm{ARM}=$ accumulation rate of minerals per unit $W$, ASiAM=accumulation of silica per unit accumulation of minerals.

b) Analysis of changes in silica content with growth of Rg and Gd.

\begin{tabular}{lrrr}
\hline $\begin{array}{lrr}\text { Forages } \\
\text { Interval(days) }\end{array}$ & $\begin{array}{r}\mathrm{Rg} \\
28\end{array}$ & $\begin{array}{c}\mathrm{Gd} \\
28\end{array}$ & $\mathrm{Rg} / \mathrm{Gd}$ \\
& & & \\
\hline Silica content changes & -0.0032 & 0.0008 & -4.2782 \\
FG index & 0.5620 & 0.3974 & 1.4144 \\
FGDSiA index & -0.0057 & 0.0019 & -3.0248 \\
\hline
\end{tabular}

FG index=an index for forage growth, FGDSiA index=an index for forage growth dependent silica accumulation. 
and 0.0008 for $\mathrm{Gd}$. The negative value in $\mathrm{Rg}$ was due to its negative FGDSiA index (0.0057 ). The difference in silica content change was mainly due to the difference ini FGDSi $\wedge$ index $(-0.0057$ versus 0.0019$)$, because the difference in $F G$ index between the two forages $(0.5620$ versus 0.3974$)$ was not so large as that of FGlOSiA index.

The regalive FGDSiA index in Rg $(-0.0057)$ is related to the fact that $\overline{\mathrm{ARSi}} / \overline{\mathrm{RGR}}$ is lower than $(\mathrm{Si}), / W_{1}$, namely silica accumulation is less active than forage growth. This may cause a slight reduction in the content of silica during the growth of $\mathrm{Rg}(-0.0032)$. In contrast, the positive FGDSiA index in Gd (0.0019) brings about a slight increase in silica content $(0.0008)$ through more active silica accumulation than forage growth. It is suggested that the present method accounts analytically for how silica accumulation is related to forage growth and how this relationship shows differences between forages.

\section{Conclusions}

Equations suggested in the present study might give some information about analyses of accumulation of silica, that of minerals and changes in silica content with growth of forages. There is a necessity for examining the present method by applying it to various forages grown under different conditions.

\section{ACKNOWLEDGEMENTS}

We wish to thank Mr. Yasukatsu Yano for his skilled technical assistance in the present study.

\section{REFERENCES}

Goering, H. K. and P. J. Van Soest 1970 Forage fiber analyses. Agriculture Ilandbook (L.S. D. A.), No. 379: $1-20$

Hunt, R. 1990 Compounded growth rates. In "Basic Growth Aralysis", Lnwin Hyman Ltd., London, pI). $55-72$

Jones, L. II. F. and K. A. Harkdreck 1967 Silica in soils, plants, and arimals. Adean.Agron., 19: 107-148

Minson. D. J. 1990 Digestible energy of forage. In "Forage in Ruminant Nutrition", Academic Press, Inc., San Diego, p). 85)-149

Shimojo, M. and I. Goto 1985 Effect of soluble silica on digestion of forage with rumen fluid of goat and cellulase. Jym. J. Zootech. Sci., 56: 20-24 (in Japanese with English summary)

Shimojo, M. and I. Goto 1989 Effect of sodium silicate on forage digestion with rumen fluid of goats or cellulase using culture solutions adjusted for $\mathrm{pH}$. Anim. Feed Sci. Technol, 24: 173-177

Shimojo, M., Y. Masuda, T. Bungo, T. Kawamura and I. Goto 1995 Analytical expression for formation of indigestible materials and increase in dry matter indigestibility with growth of some tropical grasses. J. Fac. Agr, Kyushu Univ., 40: 179-188

Shimojo, M., T. Bungo, Y. Imura, M. Tobisa, N. Koga, Y. Nakano, I. Goto and Y. Masuda 1997a Art analysis of digestibility change with growth of forage. In "Present and future of rumen research". Proc. First Joint Symp. Japarb and Korea on Rumen Metab. Physiol., P-11

Shimojo, M., Y. Imura, M. Tobisa, N. Koga, T. Bungo, Y. Nakano, T. Nishihira, I. Golo and Y. Masuda 1997b Fornation of indigestible materials and increase in dry natter indigestibility in the growth of two tropical forages. J. F'ac. Agr, Kyushu Lniv., 42: $95-99$

Shimojo, Y., Y. Imura, T. Bungo, M. Tobisa, N. Koga, S. Tao, M. Yunus, Z. Yin, Y. Nakano, I. Goto and Y. Masuda 1998a Formation of indigestible materials from digestible materials and photosynthates in the growth of Rhodes grass (Chloris gayana Kunth). J. Fac. Agr, Kyushu Univ., 42: 355-360

Shimojo, M., T. Bungo, M. Tobisa, Y. Imura, N. Koga, S. Tao, M. Yunus, Z. Yin, Y. Nakano, I. Goto and Y. 
Masuda 1998b Accumulation of digestible materials and decrease in dry matter digestibility in the growth of two tropical grasses. J. Fac, Agr, Kyushu Lniv, 42; 365-372

Shimojo, M. M. Tobisa, Y. Imura, T. Bungo, N. Koga, S. Tao, M. Yunus, Z. Yin, J. Goto, Y. Nakano and Y. Masuda $1998 \mathrm{c}$ Analyses of accumulation of crude protein and decrease in its content in the growth of Chloris gayana Kunth and Lesmodium intortum (Mill.) Urb. J. Fac. Agr., Kyushu Oniv., 42 . 377-381

Shimojo, M., T. Bungo, M. Tohisa, Y. Imura, N. Koga, S. Tao, M. Yunus, Y. Nakano, I. Goto, M. Furuse and Y. Masudi 1998d Analyses of formation of indigestible materials and increase in dry matter indigestibility with growth of two tropical forages. Proc 8 th World Conf. Anim. Prod., Seoul, Korca, Vol. II. 508-509

Shimojo, M., T. Bungo, Y. Imura, M. Tobisa, N. Koga, S. Tao, M. Yunus, Y. Nakano, I. Goto, M. Furuse and Y. Masuda $1998 \mathrm{e}$ Analyses of accumulation of crude protein and decrease in its content with growth of Rhodes grass. Proc. 8th World Conf. Anim. Prod., Seoul, Korea, Vol. II 512-513

Shimojo, M., T. Bungo, S. Tao, Y. Imura, M. Tobisa, N. Koga, M. Yunus, Y. Nakano, I. Goto, M. Furuse and Y. Masuda $1998 \mathrm{f}$ Analyses of accumulation of digestible materials and decrease in dry maiter digestibility with growth of Rhodes grass. Proc. 8th. World Conf. Anim. Prod., Seoul, Korea, Vol. II: $516-517$

Shimojo, M., T. Bungo, Y. Imura, M. Tobisa, N. Koga, S. Tao, M. Yunus, Y. Nakano, I. Goto, M. Furuse and Y. Masuda $1998 \mathrm{~g}$ Some aspects on the analysis of the formation of indigestible materials with growth of forages. Proc, 8th World Conf. Antim, Prod., Seoul, Korea, Vol. II. 518-jin 19

Shimojo, M., T. Bungo, Y. Imura, M. Tobisa, N. Koga, S. Tao, M. Yurus, Y. Nakano, I. Goto, M. Furuse and Y. Masuda $1998 \mathrm{~h}$ Accumulation rate of digestiblematerials and formation rate of indigestible materials in the description of relative growth rate of forages. J. Fac. Agr., Kyushu Lniv., 43: 119-126

Shimojo, M., 'T. Bungo, M. Tobisa, Y. Imura, N. Koga, S. Tao, M. Yunus, Y. Nakano, I. Goto, M. Furuse and Y. Masuda 1998i An application of growth analysis method to simple correlation analysis between dry matter indigestibility and lignin content with growth of a forage. I. Fac. Agr., Kyushu Lniv., 43: $127-136$

Shimojo, M., T. Bungo, Y. Imura, M. Tobisa, N. Koga, T. Shao, M. Yunus, Y. Nakano, I. Goto, M. Furuse and Y. Masuda 1999a Two-different type equations of relative growth analysis for both forages and ruminants and deriving of them from a hypothetic equation. J. Fac. Agr., Kyushu Univ., 43: in press

Shimojo, M., T. Bungo, Y. Imura, M. Tobisa, N. Koga, T. Shao, M. Yurus, Y. Nakano, I. Goto, M. Furuse and $Y$. Masuda $1999 \mathrm{~b}$ Accumulation of digestible materials with growth of forages and digestion of forage dry matter by in vitro incubation with rumen fluid and pepsin. J. Fac. Agr, Kausha Univ'., 43: in press

Shimojo, M., T. Bungo, Y. lmura, M. Tobisa, N. Koga, T. Shao, M. Yunus, Y. Nakano, I. Goto, M. Furuse and Y. Masuda $1999 \mathrm{c}$ Forage growth analysis, forage digestion analysis and ruminant growth analysis as related using simple equations. J. Fac. Agr, Kyushu Univ., 43: in press

Smith, G. S. and A. B. Nelson 1975 Effects of sodium silicate added to rumer cultures on forage digestion, with interactions of glucose, urea and minerals. :I. Anim. Sci., 41: 891-899

Smith, G. S. and N. S. Urquhart 1975 Effect of sodium silicate added to rumen cultures on digestion of siliceous forages. J. Anim. Sci., 41: 882-890

Tobisa, M., M. Shimojo, Y. Masuda and I. Goto 1997 Effects of waterlogging treatment on the contents of cell wall constituents and minerals in Aeschynomene americana cv. Glenn. Grassld. Sci., 43: 298-305 (in Japanese with English summary)

Van Soest, P. J. 1982 Nutritional quality. In "Nutritional Ecology of the Ruminant", Comell University Press, New York, pp. 23-74

Wilson, J. R. 1982 Environmental and nutritional factors affecting herbage quality. In "Nutritional Lirrits to Asimal Production from Pastures", ed. by J. B. Hacker, CAB International, Farnham Royal, L. K., pp. 111-131 